Manuscripts, and Other Special Collections. C\&RL News, March 1990. 5p. $\$ 1.00$.

- Guidelines on Manuscripts and Archives. Policy statements on: Appraisal of Gifts; Legal Title; Reproduction of Manuscripts and Archives for Noncommercial/Commercial Purposes; and Universal Gift Form and Instructions. 1977. 11p. $\$ 1.00$.

- Guidelines on the Selection of General Collection Materials for Transfer to Special Collections. CむRL News, September 1987. 4p. $\$ 1.00$.
- Guidelines Regarding Thefts in Libraries. C URL News, March 1988. 4p. \$1.00.

- Joint Statement on Access to Original Research Materials. C\&RL News, April 1979. 2p. $\$ 1.00$.

- Relator Terms for Rare Book, Manuscript, and Special Collections Libraries. C \&RL News, October 1987. 5p. $\$ 1.00$.

- Standards for Ethical Conduct for Rare Book, Manuscript, and Special Collections Librarians. C $U R L$ News, March 1987. 2p. \$1.00.

\title{
How to become an ACRL author
}

\section{Questions and answers on submission procedures.}

Are you ...

- interested in collecting information/data of interest to others in the profession?

- finding answers to some questions you have been asking?

- ready to share your ideas about academic librarianship with others in the field?

ACRL wants to publish practical and timely information of interest to academic and research librarians. Review the following information to see where your idea will best fit into the ACRL publications program.

\section{Whocan submitmaterials for publication by ACRL?}

Any individual or ACRL unit. Typically, units within ACRL sections seek approval of the Section Executive Committee before submitting a proposal.

What kind of material does ACRL publish?

ACRL will consider any publication proposal on a topic of interest to academic librarians. Proposals may be for a print or non-print format.

Typical ACRL publications include reports of data collection (e.g., ACRL University Library Statistics - in both print and diskette format), compilations of policies and procedures (e.g., CLIP Notes: Collection Development Policies for College
Libraries, Performance Appraisal in Academic Libraries), technical materials (e.g, Type Evidence: Thesaurus for Use in Rare Books and Manuscripts Collections), directories (e.g., Directory of Curriculum Materials Centers), conference proceedings (e.g., Western European Studies: Current Research Trends and Library Resources), scholarly monographs (e.g., Publications in Librarianship), pamphlets (e.g., Evaluating Information Sources), posters (e.g., Great Minds series) and bibliographies.

What are the criteria for selection?

- Importance. Is your topic significant and timely?

- Interest. Will your topic appeal to the intended audience?

- Uniqueness. Does your topic make a unique contribution to the literature? How does it relate to existing works?

- Intellectual quality. Have you adequately described and documented theory and/or practice?

- Technical quality. Is your proposal well conceived and executed? Is your writing clear and easy to understand and well organized?

- Author's qualifications. Do you have the experience, training, or research information to write on this topic? 


\section{Publishing opportunites}

New Publications Advisory Board

- coordinates ACRL's non-periodical publishing program

format

evaluates proposals for works of any length or

- sends on request a "Preliminary Publication Information" form and ACRL publishing procedures

Contact: Mary Ellen Davis, Director of Communications, ACRL, 50 E. Huron St., Chicago, IL 60611 , (800) 545-2433 x2515 or (312) 280-2515.

\section{ACRL Periodicals}

ACRL's active periodical publishing program welcomes the submission of manuscripts.

- College \& Research Libraries-ACRL's bimonthly, scholarly journal

- College d-Research Libraries News-ACRL's monthly news magazine

- Rare Books and Manuscripts Librarianshipjournal of theory and practice covering special collections librarianship

- Choice-book review journal for undergraduate libraries

- Section newsletters-14 library sections pub- lish newsletters of particular interest to their membership

Contact: Please check a recent issue of the periodical you are interested in for current editor/ contact person and submission procedures.

\section{CLIP Notes}

College Library Information Packet Notes, administered by ACRL's College Libraries Section, provides ideas for managing academic library programs and services through reporting data and providing sample documents on current topics. The CLIP Notes Committee accepts and evaluates proposals and works with authors.

Contact: CLIP Notes Committee Chair, Jonathan Lauer, Director, Messiah College, Murray Learning Resources Center, Grantham, PA 17027; (717) 691-6006.

\section{ACRL Publications in Librarianship}

This series, published by ALA, solicits monographs pertinent to all aspects of academic and research librarianship.

Contact: Jonathan Lindsey, Dir., Corp. \& Fdn. Development, Baylor University Library, B.U. Box 7026, Waco, TX 76798-7026; (817) 755-2561.

Choice Bibliographic Essays

This series, published by Choice magazine, is for

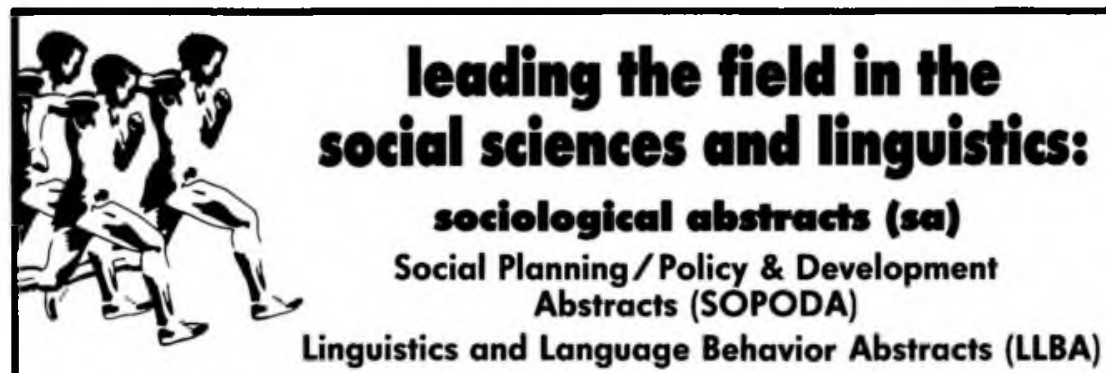

Our subject specialists track the brood spectrum of theoretical and applied sociology and linguistics from the more than 1,900 discipline-specific and related journals published in North America, Europe, Asia, Africa, Australia, and South America.

an, SOPODA and LLBA each offer you in-depth abstracts and precise indexing of timely journal articles and books, enhanced dissertation listings, and a bibliography of book reviews from the journals screened. sa and SOPODA are available together on the sociofile CD-ROM and are hosted online by BRS, DATA-STAR, DIALOG, and DIMDI. Hard-copy subscriptions can be ordered from the address below.

LLBA can be accessed online from BRS and DIALOG and is also available in print from our subscription office.

Your fast track to the information you need, in the format you want.

phone (619) 695-8803/FAX (619) 695-0416/Help Desk (800) 752-3945 
bibliographies on selected topics of interest to academic and research librarians.

Contact: Patricia E. Sabosik, Choice Magazine, 100 Riverview Center, Middletown, CT 06457; (203) 347-6933.

\section{Procedures}

- Identify a topic.

- Develop an outline for a publication.

- Review written guidelines, selection criteria, and procedures for ACRL publications.

- Submit a proposal or manuscript to the appropriate person for consideration. Include a completed Preliminary Publication Proposal Form (available upon request from ACRL Headquarters).

- Wait 6-8 weeks to receive one of four possible responses:

- acceptance of proposed publication;

- acceptance, with recommendations for modifications;

- return, with recommendations for change and/or resubmission to other ACRL program; or

- return, with regrets.

Questions about ACRL publishing may be addressed to: Mary Ellen Davis, director of communications, (800) $545-2433 \times 2515$ or (312) 280 2515.

\section{Summer study in Britain 1991}

The 19th annual International Graduate Studies School will be held June 29-August 10 at the University College of Wales, Aberystwyth, Wales, U.K. This year there will be two sessions, each three weeks long. From June 29 to July 20, courses will be offered on audiovisual studies, computers and automation, and library management. Between July 20 and August 10, courses will cover library development planning, information management, and management of change. Students will continue to be able to take two courses over six weeks, or can take just one course in either session. IGISS is organized by the Department of Informa- tion and Library Studies at the University College of Wales in association with the University of Pittsburgh School of Library and Information Science. Courses carry graduate academic credits, and qualified students may use them as part of their MLS or advanced programs in most graduate schools in the U.S. and Canada. The comprehensive fee, which includes all tuition, accommodation, and meals, is $£ 1,800$ for six weeks or $£ 900$ for three weeks. Details: Department of Information \& Library Studies, University College of Wales, Llanbadarn Fawr, Aberystwyth, Dyfed, SY23 3AS, Wales, Great Britain.

\section{ACRL board votes to withdraw 6th national conference from Phoenix}

The 1991 ACRL Board of Directors unanimously passed a resolution Sunday, January 13, to move its 6th national conference from Phoenix, Arizona, due to the state's refusal to recognize the national holiday in honor of the late Dr. Martin Luther King, Jr. The conference was originally scheduled to be held in Phoenix on April 1-4, 1992. The resolution states: "When Martin Luther King, Jr. Day becomes a state holiday in Arizona, ACRL will schedule its next available national conference in Phoenix."

The ACRL board met at the Chicago Hilton and Towers during the ALA Midwinter Meeting attended by some 7,000 librarians and exhibitors.

ACRL president Barbara J. Ford thanked the Arizona State Library Association for its cooperation and said that the ACRL Board looks forward to working with them in the future."We withdrew from Phoenix to show our support for those in
Arizona who want to recognize Dr. King's birthday with a paid holiday," said Shelley Phipps, ACRL board member and librarian at the University of Arizona, Tucson.

The action comes after the Black Caucus of ALA (BCALA) passed a resolution January 11 urging the ACRL National Conference Planning Committee to reconsider the Phoenix site.

"If we stay in Phoenix, we lose the trust of our colleagues," said Sherrie Bergman, a member of the ACRL National Conference Executive Committee.

"Deciding not to hold our conference in Phoenix is the only decision we can make-ethically, politically, and morally," said ACRL board member Evan Farber.

The board is investigating other options for the 6 th national conference. Plans will be announced in an upcoming issue of C $b R L$ News. 


\section{Introducing... \\ ENVIRO/ENERCYLINE \\ Abstracts Plus ${ }^{\text {TM }}$

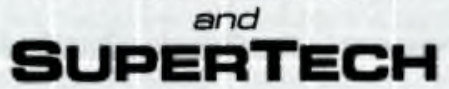 \\ Abstracts P/us ${ }^{\mathrm{TM}}$ \\ CD-ROM research and delivery systems focusing on today's most crucial areas of scientific endeavor.}

Have mobile robots mastered visual novigation?

Will Japan cutpace the U.S. in neural network applications?

Where can I find the latest patents on computer graphics?

\section{ВUPEATECH}

Abetrecte Plus
How much plastic waste material is recreled?

What papors were delivered at ASME's Internotional Solar Enargy Conference?

Which states have enacted legislation to fight acid rain?

ENVIRC/ENERGVLINE Abatracte Plus

\section{THERE ARE SIMPLE ANSWERS TO ANY OF YOUR QUESTIONS!}

\section{ENVIRO/ENERGYLINE Abatracts Plus or BupeaTech Abatracte Plua}

For years Bowker A \& I Publishing has been collecting, classifying, and digesting over 10,000 technical and non-technical sources in the environmental and high-tech fields. Now we've converted our A \& I databases into flexible CD-ROM format-and produced a viable solution to the problem of rising serials prices and publishing activity. For the price of a few professional journals, you'll extend your coverage and enjoy unrestricted CD-ROM access to an international clearinghouse of scientific, public policy, economic, legal, and consumer-oriented research.

A \& I's information-packed databases and the powerful retrieval software similar to other of Bowker's Plus System ${ }^{* 4}$ CD-ROM products, will not only speed up the research process, but also improve the quality and content of your results with...

- On-site, immediate 24-hour access to the resources normally dispersed among hundreds of specialized collections.

- On Hand or On Demand exploration of documents at their source through companion microfiche collections or ordering directly through your computer-or by phone or fax.

- Fielded and full-text searching by custom searching each CD-ROM by combining 16 traditional points of entry, such as title, subject, author, date, document type, and more.

- Cumulative, quarterly updates to keep you current on the latest trends, issues, and advances.

\section{Call us today TOLL-FREE 1-800-323-3288 for details.}

Bowker Electronic Publishing - 121 Chanlon Road - New Providence, NJ 07974 